\title{
A survey of psychotherapy training among psychiatric trainees
}

\author{
Ross J. Hamilton and Diana Tracy
}

\begin{abstract}
The Royal College of Pyychlatrists has stressed that psychotherapy skills are seen as a core element of poychiatric practice. To formallse this a new set of guidelines for poychotherapy training as part of general professtonal peschiatile training was published in November 1993. Concerns have been expressed over the implementation of previous guidelines from 1986. We have surveyed the peychotherapy training experience in our area and have worked with the psychotherapy department to address the findings. The future of training in the peychotheraples and implementation of the most recent guidellines are considered.
\end{abstract}

In November 1993 new guidelines for psychotherapy training as part of general professional psychiatric training were published in the Psychiatric Bulletin (Royal College of Psychiatrists, 1993). These guidelines replace those from 1986 and represent a joint statement from the General Psychiatry Section and the Psychotherapy Section of the Royal College of Psychiatrists. The guidelines describe the objectives of training, teaching methods, clinical experience, theoretical teaching, occupational stress, team working, and organisational requirements and difficulties.

Arnott et al (1993) compared the psychotherapy training in their region in 1993 with the 1986 College guidelines. Their survey implied that trainees were not receiving adequate supervision and training in accordance with the 1986 guidelines. One year on from the introduction of the new guidelines (1993) we decided to look at trainees' experience of psychotherapy supervision and compare their clinical experience with the new guidelines. Theoretical aspects of psychotherapy training were well covered locally in the local postgraduate MRCPsych programme and also at an introductory course in psychotherapy which was open to all psychiatric trainees as well as to staff in other disciplines.

\section{The study}

With the duty roster a confidential postal self report questionnaire was sent to all psychiatric trainees in the last two weeks of January 1995. It was felt that this was a time of maximum stability as all trainees would have had at least five and a half months of psychiatric training locally. Stage of training was identified as pre- and postMembership examination. Trainees were asked to complete a questionnaire (Table 1), and indicate which aspects of supervision they found most helpful, e.g. theoretical grounding, technical skills, peer support or supervisor support. Other comments on supervision were also invited.

\section{Findings}

The response rate of psychiatric trainees was $73 \%$ (19/26; six were pre-Membership and 13 were post-Membership).

All trainees had been in post for at least five and a half months, and the majority for much longer. Just under three-quarters of psychiatric trainees were currently seeing a psychotherapy patient.

Supervision groups form the mainstay of psychotherapy supervision in our area and only three trainees were receiving other types of supervision. All three of these trainees were also receiving supervision within groups. Two trainees were not receiving supervision. Fewer than half of trainees were familiar with the current psychotherapy training guidelines.

The majority of trainees had experience of longterm and brief dynamic psychotherapy. The same can not be said of cognitive-behavioural therapy in which $14 / 19(74 \%)$ trainees were either inexperienced or unsupervised. Of the comments volunteered in the survey, the lack of cognitivebehavioural therapy training was the most frequently expressed.

\section{Comment}

The study performed by Arnott et al (1993) of a similar sized training scheme in Bristol to compare training in their area with 1986 College guidelines suggested that the deficiencies found were not confined to their region. Our study in northern Scotland confirms that two years on with new guidelines this is indeed the case. This survey shows that in our area experience falls short of the guidelines in relation to cognittivebehavioural therapy and to a lesser degree, to 
Table 1. Trainees' questionnaire

\begin{tabular}{|c|c|c|c|}
\hline \multicolumn{4}{|l|}{ Trainees' involvement in a supervision group ( $n=19)$} \\
\hline $\begin{array}{l}\text { Currently seeing a psychotherapy patient } \\
\text { Part of a group } \\
\text { Supervised outwith a group } \\
\text { Famillar with guidelines for training }\end{array}$ & & $\begin{array}{l}\text { Yes } \\
14(74 \%) \\
17(89 \%) \\
3(16 \%) \\
9(47 \%)\end{array}$ & $\begin{array}{l}\text { No } \\
5(26 \%) \\
2(11 \%) \\
16(84 \%) \\
10(53 \%)\end{array}$ \\
\hline $\begin{array}{l}\text { Trainees' experience in specific areas (n=19) } \\
\text { Long-term indlvidual dynamic psychotherapy case } \\
\text { Brief indlvidual dynamic psychotherapy case } \\
\text { Intenstive indlidial behavioural/cognittive psychotherapy case } \\
\text { Brief indlvidual behavioural/cognittive psychotherapy cases } \\
\text { Group therapy } \\
\text { Marttal and family therapy }\end{array}$ & $\begin{array}{l}\text { No experience } \\
4(21 \%) \\
4(21 \%) \\
10(53 \%) \\
9(48 \%) \\
11(58 \%) \\
7(37 \%)\end{array}$ & $\begin{array}{l}\text { Supervised } \\
14(74 \%) \\
14(74 \%) \\
5(26 \%) \\
5(26 \%) \\
7(37 \%) \\
11(58 \%)\end{array}$ & $\begin{array}{l}\text { Unsupervised } \\
1(5 \%) \\
1(5 \%) \\
4(21 \%) \\
5(26 \%) \\
1(5 \%) \\
1(5 \%)\end{array}$ \\
\hline $\begin{array}{l}\text { Aspects of supervision reported as helpful }(n=17) \\
\text { Theoretical aspects } \\
\text { Technical skills } \\
\text { Peer support } \\
\text { Supenvisor support }\end{array}$ & & $\begin{array}{l}\text { Yes } \\
5(29 \%) \\
10(5 \% \%) \\
10(59 \%) \\
14(82 \%)\end{array}$ & $\begin{array}{l}\text { No } \\
12(71 \%) \\
7(41 \%) \\
7(41 \%) \\
3(18 \%)\end{array}$ \\
\hline
\end{tabular}

group, family and marital therapy. Dynamic psychotherapy is, however, well covered.

There is increasing interest in the cost-effectiveness of the briefer therapies, e.g. cognitivebehavioural therapy in chronically anxious patients (Durham et al, 1995), and, in the future, brief therapies will be increasingly attractive to purchasers. It seems important that trainees in psychiatry should be familiar with all forms of therapy. It has been suggested that training in psychotherapy which meets these guidelines might become obligatory for entry to the MRCPsych Part II examination. However, this would require some policing and a new strategy. such as log-books, would have to be introduced. We would support this as a way of ensuring a more eclectic training for all psychiatric trainees. The changes in the structure of training through the introduction of the specialist registrar grade present an opportunity to introduce a more rigorous method of ensuring that all psychiatric trainees have adequate supervised training in all major forms of psychotherapy. The results of our survey were presented to the local Psychotherapy Forum, a weekly multidisciplinary group who share an interest in psychotherapy teaching and practice. From this a series of meetings ensued between the authors, current trainees in psychiatry and the supervision group leaders with the aim of addressing the deficiencies identified.

At the time of writing the following modifications to psychotherapy training are under way: (1) the psychiatric trainees' induction course, held at six monthly intervals for new trainees, will include a presentation on supervision for trainees and will detail the College guidelines on psychotherapy training; (2) all groups will be encouraged to meet regularly when the group supervisor is absent as a percetved lack of peer support is an important finding in this study; (3) negotiations are proceeding to allow cognittve-behavioural training to become available to all trainees.

Overall, we support the College guidelines as set out in 1993 but are concerned that in two geographically distant areas of the UK surveys of trainees suggest that their breadth of experience falls short of the standard and a majority of trainees are unaware of the guideline recommendations.

\section{References}

Royal CoLlege of PSYchiatrists (1993) Guidelines for psychotherapy training as a part of general professional training. Psychiatric Bullettr. 17, 695-698.

- (1986) Guidelines for the training of general psychiatrists in psychotherapy. Bullettn of the Royal College of Psychiatrists, 10, 286-289.

ARnott, S., WIKInson, E. \& AYrard, P. (1993) A survey of psychotherapy experience amongst psychlatric registrars. Psychiatric Bulletin, 17, 721-723.

DURHAM, R. C., MURPHY, T., ALIAN, T., et al (1994) Cognittve therapy, analytic psychotherapy and anxiety management training for generalised anxiety disorder. Brtish Journal of Psychiatry, 165. 315-323.

*Ross Hamilton, Senior Registrar; and Diana Tracy, Senior Registrar, Royal Cornhill Hospital, Cornhill Road, Aberdeen AB9 2ZH

*Correspondence 